\title{
PROFIL PROTEIN TIROSIN KINASE DALAM SEMINAL PLASMA DOMBA MERINO DENGAN TEKNIK SODIUM DODECYL SULPHATE POLYACRILAMIDE GEL ELECTROPHORESIS
}

\section{TYROSINE KINASE PROTEIN PROFILE IN SEMINAL PLASMA OF MERINO SHEEP WITH SODIUM DODECYL SULPHATE POLYACRILAMIDE GEL ELECTROPHORESIS}

\author{
Tantri Nawangwulan'), Sri Pantja Madyawati' ${ }^{2}$, Hani Plumeriastuti ${ }^{3)}$, Trilas \\ Sardjito $^{4)}$, Suherni Susilowati ${ }^{5)}$, Erma Safitri ${ }^{6)}$ \\ ${ }^{1)}$ Student, ${ }^{2,4,5,6)}$ Veterinary Reproduction Department ${ }^{3)}$ Veterinary Patology Department \\ Faculty of Veterinary Medicine, Airlangga University \\ email: tantrinawang16@gmail.com
}

\begin{abstract}
The aim of this study was to find out protein tyrosine kinase profile in Merino Sheep seminal plasma. This study consist of collecting semen of Merino Sheep containing plasma and spermatozoa, the separation between seminal plasma and spermatozoa, then tyrosine kinase analysis using Sodium Dodecyl Sulphate Polyacrilamide Gel Electrophoresis (SDS-PAGE). Semen was collected by artificial vagina and then centrifugated for 40 minutes at $4000 \mathrm{rpm}$ to separated seminal plasma and spermatozoa. Protein was analyzed using SDS-PAGE, to separate each protein based on their molecular weight. The result showed that there were 13 protein bands in 3 seminal plasma samples with an average 149,63 kDa, 139,7 kDa, 114,97 kDa, 109,3 $\mathrm{kDa}, 97,33 \mathrm{kDa}, 93,83 \mathrm{kDa}, 86,23 \mathrm{kDa}, 77,6 \mathrm{kDa}, 64,6 \mathrm{kDa}, 52,3 \mathrm{kDa}, 41,93 \mathrm{kDa}, 38,13 \mathrm{kDa}$, and $34,5 \mathrm{kDa}$. In conclusion, it is believed that tyrosine kinase located on the sixth band with molecular weight $93,83 \mathrm{kDa}$.
\end{abstract}

Keyword : Tyrosine Kinase, SDS-PAGE

\section{Pendahuluan}

Daging domba seperti halnya daging ayam, dapat diterima oleh berbagai lapisan masyarakat (Sudarmono dan Sugeng, 2003). Hal ini diketahui dari laju permintaan daging domba meningkat rata-rata $2,7 \%$ per tahun, namun belum diikuti dengan ketersediaan ternak domba dalam negeri (Mulyono dan Sarwono, 2014). Upaya peningkatan produktivitas reproduksi dapat dicapai salah satunya dengan bioteknologi. Bioteknologi reproduksi yang telah diterima oleh masyarakat peternak dalam meningkatkan produksi ternak adalah superovulasi, yaitu cara reproduksi yang digunakan untuk menghasilkan kelahiran kembar dan teknologi inseminasi buatan(IB) yang bertujuan untuk memanfaatkan potensi seekor hewan jantan unggul secara maksimal. Inseminasi buatan pada domba masih belum berkembang dan bersifat percobaan, hal ini dikarenakan pengelolaan peternakan domba di Indonesia yang masih bersifat tradisional (Hardijanto dkk., 2010). Sampai saat ini, belum ada publikasi keberhasilan IB pada kambing dan domba pada kondisi lapang di Indonesia, namun diprediksi tingkat kebuntingannya masih dibawah 30\% (Djemali et $a l, 2009)$.

Semen yang umum digunakan pada program IB adalah semen beku. Hal ini bertujuan untuk memperluas jangkauan distribusi semen, disamping memperpanjang umur penyimpanan semen tersebut. Namun pada pembuatan semen beku dapat mengakibatkan kerusakan fisik dan kimia pada membran spermatozoa yang dapat mempengaruhi viabilitas dan motilitasnya (Baumber et al, 2003). Membran sel spermatozoa adalah selaput tipis bersifat semipermiabel sehingga perubahan tekanan osmosis yang mendadak dapat meyebabkan kejutan osmosis sehingga berakibat pada penurunan viabilitas spermatozoa dan kerusakan membrane (Moce dan Graham, 2008). Selain itu, rendahnya angka fertilitas pada domba juga dapat disebabkan karena 
semen domba lebih sensitif terhadap cold shock di banding dengan spesies lain (Muino-Blanco et al., 2008). Cold shock terjadi karena penurunan suhu yang cepat sehingga dapat menurunkan viabilitas dan motilitas spermatozoa dan dan daya hidup. Pembentukan kristal es saat proses kriopreservasi menyebabkan menumpuknya elektrolit di dalam sel yang akan merusak dinding sel spermatozoa saat pencairan kembali sehingga permeabilitas membran plasma menurun dan menyebabkan kematian sel spermatozoa (Watson, 2000).

Permasalahan dalam pembuatan semen beku di atas, telah banyak studi yang dilakukan untuk meminimalkan kerusakan tersebut diantaranya adalah penambahan tirosin kinase sebagai suplementasi ke dalam semen beku. Tirosin kinase merupakan salah satu molekul protein yang tedapat pada membran plasma spermatozoa (Morales and Llanos., 1996). Naz dan Ahmed (1994) juga menyatakan beberapa protein membran spermatozoa pada tikus yang memiliki kemampuan mengikat protein zona pelusida sel telur mempunyai berat molekul 95, 63, dan 14-18 $\mathrm{kDa}$. Namun yang memiliki aktivitas autofosforilasi paling potensial adalah protein dengan berat molekul $95 \mathrm{kDa}$.

\section{Alat dan Bahan}

Alat dan bahan yang digunakan pada penelitian ini adalah semen domba Merino, vagina buatan, acrylamide, Tris-HCL, Tetra methylene diammine(TEMED), Ammonium per sulphate (APS), glycine, sodium dedocyl sulphate(SDS), alkohol, coomasie blue, box pendingin, Blotter (Bio-Dot Apparatus, BIORAD-USA), microplate, vacuum pump, pipet, eppendorf, plastik tip, tabung reaksi, freezer, autoclaf, micropipet, labu takar, kertas lakmus, neraca analitik (sartorius basic P-160), tabung sentrifugasi, alat sentrifugasi (Denley tipe BR 401), vortex (Guo-Huq), sonikasi (Branson 200), spektrofotometer UV, mini 2D elektroforesis protein II (Biorad).

\section{Metode Penelitian}

\section{Tahap Penampungan Semen Segar} Domba Merino

Semen diperoleh dari 2 ekor domba Merino jantan yang berada di Taman Ternak Pendidikan dan Unit Semen Beku FKH
Unair, Gresik. Domba Merino betina digunakan sebagai pemacek lalu semen ditampung mengggunakan vagina buatan yang telah di isi dengan air hangat $40-45^{\circ} \mathrm{C}$ dan di olesi vaselin.

\section{Tahap Pemeriksaan Makroskopis dan Mikroskopis Semen Segar Domba Merino}

Sampel semen yang diperoleh dilakukan pemeriksaan makroskopis yang meliputi volume, bau, warna, konsistensi serta $\mathrm{pH}$ dan mikroskopis yaitu gerakan massa, gerakan individu dan konsentrasi. Pemeriksaan tersebut bertujuan untuk memutuskan apakah semen yang diperoleh layak untuk dijadikan sampel pada analisis SDS-PAGE.

\section{Tahap Pemisahan Spermatozoa Dengan Plasma Seminalis Domba Merino}

Semen yang diperoleh dipindahkan ke tabung sentrifuge untuk di sentrifugasi dengan kecepatan 4000 rpm selama 40 menit guna memisahkan pellet (spermatozoa) dengan supernatan (plasma seminalis). Selanjutnya akan terpisah menjadi bagian yang atas dan bawah, bagian yang atas yaitu plasma seminalis diambil dan dimasukkan dalam tabung mikrotub untuk disimpan dalam freezer.

\section{Tahap Pemurnian Protein}

Plasma seminalis perlu dimurnikan untuk mengetahui protein dari plasma seminalis. Proses permurnian diawali dengan sentrifugasi plasma seminalis selama 10 menit dengan kecepatan $3000 \mathrm{rpm}$. Setelah itu ditambahkan dengan PBST-PMSF 5 kali dari volume plasma kemudian di vortex agar tercampur secara homogen. Sonikasi selama 10 menit dan sentrifugasi kembali dengan kecepatan $6000 \mathrm{rpm}$ selama 10 menit. Setelah di sentrifugasi agar terpisah plasma dengan endapan. Plasma tersebut ditambah dengan etanol 1:1 lalu disimpan selama 1 hari untuk selanjutnya dilakukan proses running SDS-PAGE.

\section{Tahap Analisis pita protein dengan teknik SDS-PAGE}

Langkah kerja dari teknik SDS-PAGE meliputi pembuatan gel pemisah atau separating gel, pembuatan gel pengumpul atau stacking gel, dilarutkan running pada plate, pewarnaan, lalu selanjutnya direndam 
dalam larutan destaining untuk pencucian. Tahap pertama adalah memasukkan separating gel ke dalam alat elektroforesis melalui dinding sampai di bawah batas atas. Apabila separating gel telah merata dan keras, maka tambahkan stacking gel melewati dinding sampai penuh, masukkan comb (pencetak sumuran dari gel) dan ditunggu sampai terbentuk gel. Selanjutnya comb diambil dan dibersihkan dari sisa gel dengan tisue. Cetakan gel yang sudah jadi dipindahkan dan dimasukkan ke dalam chamber, kemudian direndam dalam running buffer. Selanjutnya diletakkan cetakan penuntun sampel yang akan di running.

Tahap Selanjutnya yaitu proses menambahkan atau injeksi sampel. Sebanyak $35 \mu$ plasma seminalis domba dimasukkan ke dalam lubang cetakan dengan tip $200 \mu \mathrm{l}$. Langkah berikutnya chamber dihubungkan dengan alat Biorad, power supply dinyalakan dengan kekuatan $130 \mathrm{~V}, 30 \mathrm{~mA}$ selama 1,5 jam. Jika reaksi gel sudah sampai bawah kemudian dimatikan dan plate dibuka dan dipisahkan. Selanjutnya hasilnya berupa lembaran berbentuk gel diwarnai dengan coomasie blue dan di sacker (digoyang) selama 30 menit. Kemudian dikeluarkan dan ditambahkan dengan cairan destaining dan di sacker lagi selama 30 menit. Jika cairan sudah terlihat biru diganti dengan cairan destaining yang baru begitu seterusnya sampai cairan berwarna putih dan hasilnya berupa beberapa pita protein. Berat molekul akan dapat terlihat pada cetakan gel SDS-PAGE (Rantam, 2003).

\section{Hasil dan Pembahasan \\ Pemeriksaan Makroskopis dan Mikros- kopis Semen Segar Domba Merino}

Pemeriksaan makrokopis meliputi pemeriksaan volume, derajat keasaman atau $\mathrm{pH}$, konsistensi, bau, dan warna. Pemeriksaan mikroskopis meliputi gerakan massa, gerakan individu, dan konsentrasi. Data pemeriksaan makroskopis dan mikroskopis dapat dilihat pada Tabel 1. Dan Tabel 2.

Dari hasil tersebut diatas, pada pita ke-6 dengan rerata berat molekul $93,83 \mathrm{kDa}$ yang diyakini sebagai berat molekul tirosin kinase. Hal ini sesuai dengan pernyataan Aitken et al (1995) bahwa tirosin kinase pada tikus memiliki berat molekul $95 \mathrm{kDa}$.

\section{Pembahasan}

Pemeriksaan kualitas semen secara makroskopis meliputi volume, bau, warna, pH serta konsistensi dan mikroskopis meliputi gerakan massa, gerakan individu dan juga konsentrasi. Dari pemeriksaan macroskopis didapatkan kondisi yang baik dengan rata-rata volume $1,5 \mathrm{ml}$, berwarna putih krem, kental, bau khas sengan ph 6-7. Pemeriksaan mikroskopis semen menunjukkan dalam kondisi baik dengan rata-rata gerakan massa ++/+++, gerakan indvidu $81,6 \%$ dengan kecepatan gerak 3/P. Semen dalam kondisi baik dan dapat digunakan sebagai sampel untuk analisis SDS-PAGE.

Berdasarkan hasil analisis terhadap hasil identifikasi tirosin kinase dalam plasma seminalis domba Merino didapatkan

Tabel 1. Hasil Pemeriksaan Makroskopis spermatozoa domba Merino

\begin{tabular}{ccclcc}
\hline penampungan & Volume & Bau & Warna & $\mathrm{pH}$ & Konsistensi \\
\hline 1 & $1,5 \mathrm{ml}$ & Khas & Putih krem & $6-7$ & Kental \\
2 & $1,5 \mathrm{ml}$ & Khas & Putih krem & $6-7$ & Kental \\
3 & $1,5 \mathrm{ml}$ & Khas & Putih krem & $6-7$ & Kental \\
Rata-rata & $1,5 \mathrm{ml}$ & khas & Putih krem & $6-7$ & kental \\
\hline
\end{tabular}

Tabel 2. Hasil Pemeriksaan Mikroskopis spermatozoa domba Merino

\begin{tabular}{ccccc}
\hline penampungan & $\begin{array}{c}\text { Gerakan } \\
\text { Massa }\end{array}$ & $\begin{array}{c}\text { Motilitas } \\
(\%)\end{array}$ & Kecepatan & $\begin{array}{c}\text { Konsentrasi } \\
\text { Juta/ml }\end{array}$ \\
\hline 1 & ++ & 75 & 3 & 1174 \\
2 & +++ & 85 & 3 & 1565 \\
3 & +++ & 85 & 3 & 2003 \\
Rata-rata & +++++ & 81,6 & 3 & 1580 \\
\hline
\end{tabular}


Tabel 3. Hasil rata-rata berat molekul protein plasma seminalis domba Merino

\begin{tabular}{|c|c|c|c|c|}
\hline No & Sampel 1 & Sampel 2 & Sampel 3 & Rata-rata \\
\hline 1 & $150,5 \mathrm{kDa}$ & $150,5 \mathrm{kDa}$ & $147,9 \mathrm{kDa}$ & $149,63 \mathrm{kDa}$ \\
\hline 2 & $141,9 \mathrm{kDa}$ & $138,6 \mathrm{kDa}$ & $138,6 \mathrm{kDa}$ & $139,7 \mathrm{kDa}$ \\
\hline 3 & $116,3 \mathrm{kDa}$ & $116,3 \mathrm{kDa}$ & $112,3 \mathrm{kDa}$ & $114,97 \mathrm{kDa}$ \\
\hline 4 & $109 \mathrm{kDa}$ & $111 \mathrm{kDa}$ & $107,1 \mathrm{kDa}$ & $109,03 \mathrm{kDa}$ \\
\hline 5 & $97,5 \mathrm{kDa}$ & $97 \mathrm{kDa}$ & $97,5 \mathrm{kDa}$ & $97,33 \mathrm{kDa}$ \\
\hline 6 & $94,2 \mathrm{kDa}$ & $93,1 \mathrm{kDa}$ & $94,2 \mathrm{kDa}$ & $93,83 \mathrm{kDa}$ \\
\hline 7 & $85,2 \mathrm{kDa}$ & $87,8 \mathrm{kDa}$ & $85,7 \mathrm{kDa}$ & $86,23 \mathrm{kDa}$ \\
\hline 8 & $76,7 \mathrm{kDa}$ & $77,6 \mathrm{kDa}$ & $78,5 \mathrm{kDa}$ & $77,6 \mathrm{kDa}$ \\
\hline 9 & $63,6 \mathrm{kDa}$ & $63,6 \mathrm{kDa}$ & $66,6 \mathrm{kDa}$ & $64,6 \mathrm{kDa}$ \\
\hline 10 & $53,3 \mathrm{kDa}$ & $51,5 \mathrm{kDa}$ & $52,1 \mathrm{kDa}$ & $52,3 \mathrm{kDa}$ \\
\hline 11 & $41,7 \mathrm{kDa}$ & $42,4 \mathrm{kDa}$ & $41,7 \mathrm{kDa}$ & $41,93 \mathrm{kDa}$ \\
\hline 12 & $37,1 \mathrm{kDa}$ & $39,4 \mathrm{kDa}$ & $37,9 \mathrm{kDa}$ & $38,13 \mathrm{kDa}$ \\
\hline 13 & $34,7 \mathrm{kDa}$ & $34,1 \mathrm{kDa}$ & $34,7 \mathrm{kDa}$ & $34,5 \mathrm{kDa}$ \\
\hline
\end{tabular}

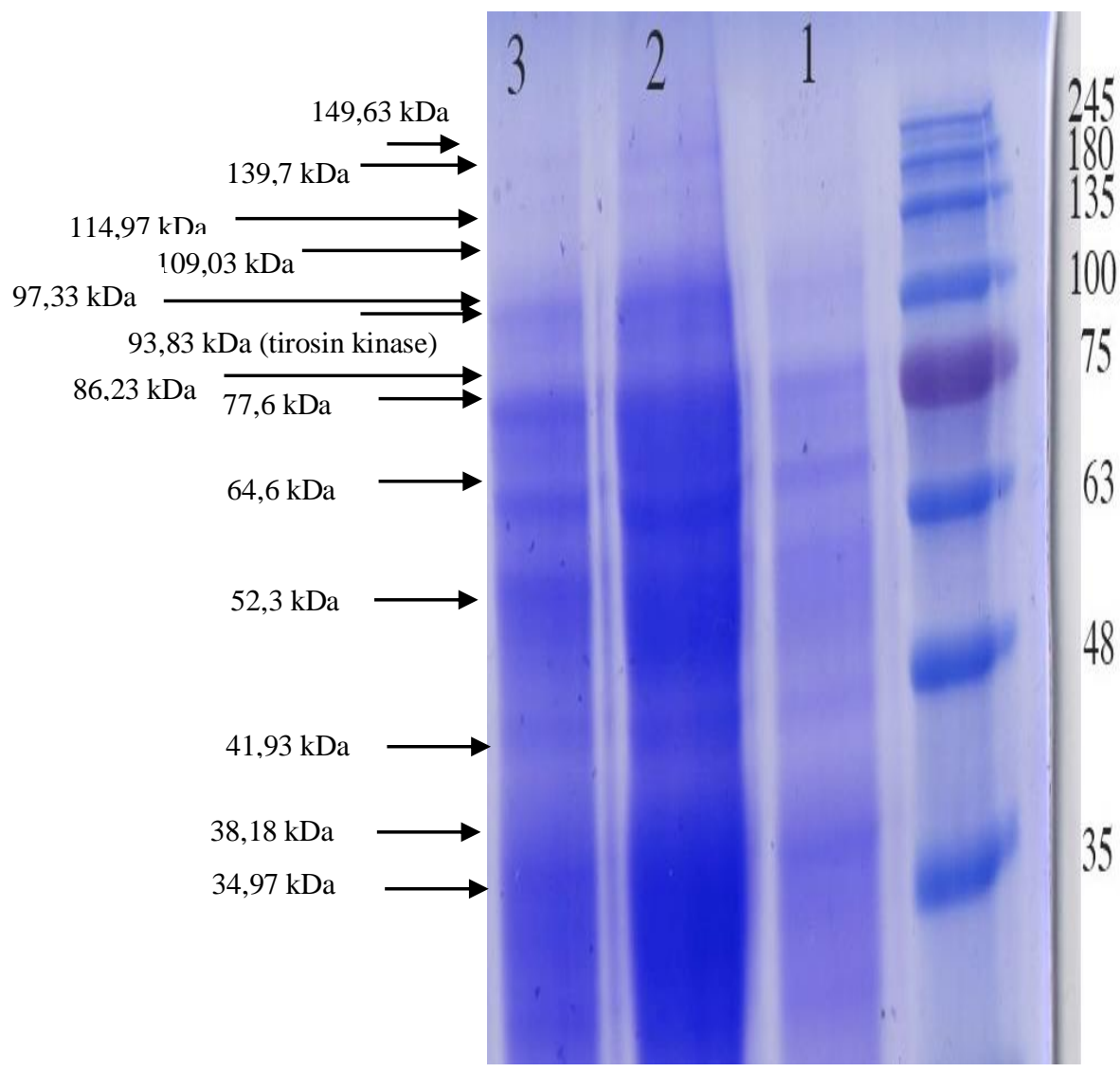

Gambar 1. Pita protein plasma seminalis hasil SDS-PAGE

Hasil identifikasi profil protein plasma domba Merino diperoleh 13 pita protein dengan tirosin kinase pada pita ke-6 dengan berat molekul 93,83 kDa. Partikel yang memiliki berat molekul sama akan terakumulasi di titik yang sama, sehingga membentuk beberapa pita dengan panjang ber beda yang terpisah berdasarkan berat mole- kulnya (Hames, 2004). Pada hasil analisis protein yang diperoleh, pita yang muncul nampak tipis dan kurang begitu terlihat. Tebal tipisnya pita yang terbentuk menunjukkan kandungan atau jumlah protein yang memiliki berat molekul sama yang berada pada posisi pita yang sama. Sesuai dengan prinsip pergerakan molekul bermuatan, 
molekul dengan muatan serta ukuran yang sama akan terakumulasi pada titik yang sama atau berdekatan (Soedarmadji, 1996). Selain itu kualitas semen yang digunakan juga berpengaruh pada hasil dari analisis SDS-PAGE. Pengaruh pakan yang diberikan dapat mempengaruhi kualitas dari semen yang dihasilkan. Jumlah pakan yang kurang akan menghambat pertumbuhan dan fungsi reproduksi pejantan melalui pengaruhnya terhadap sekresi hormon-hormon gonadotropin, sedangkan jumlah pakan yang berlebihan menyebabkan pejantan mengalami kegemukan sehingga tidak mampu berkopulasi karena kelemahan kaki belakang dan penurunan libido. Libido juga dapat mempengaruhi kualitas semen, apabila frekuensi penampungan semen terlalu sering makan akan menurunkan libido dari pejantan tersebut (Toelihere, 1993), sedangkan libido yang tinggi dapat meningkatkan volume dan konsentrasi spermatozoa motil per ejakulasi (Wodzicka dkk., 1991). Faktor lain yang juga dapat mempengaruhi kualitas semen adalah suhu lingkungan. Suhu optimal spermatogenesis adalah $33^{\circ} \mathrm{C}-36^{\circ} \mathrm{C}$. Apabila suhu dibawah itu makan akan merusak produksi spermatozoa, dan apabila suhu terlalu tinggi akan menyebabkan abnormalitas spermatozoa (Boothby dan Fahey dalam Munfarida, 2004).

\section{Kesimpulan}

Terdapat 13 pita protein pada plasma seminalis domba Merino. Pita protein tirosin kinase diyakini terdapat pita ke-6 dengan berat molekul 93,83 $\mathrm{kDa}$.

\section{Daftar Pustaka}

Baumber J, Ball BA, Linfor JJ, Meyers SA. 2003. Reactive oxygen species and cryopreservation promote DNA fragmentation in equine spermatozoa. Androl 24: 621-628.

Djemali M, Romdhani BS, Iniguez L, Inounu I. 2009. Saving threatened native breeds by autonomous pro- duction, involvement of farmers organization, research and policy makers: The case of the Sicilo-Sarde breed inTunisia, North Afri-ca. Livest Sci. 120:213-217.

Hames, B.D \& Rickwood. 2004. A Practical Approach: Gel elektrophoresis protein. Huntington: Robert E Krieger Publishing Com-pany.

Hardijanto, S. Susilowati, T. Hernawati, T. Sardjito, dan T. W. Suprayogi. 2010. Buku Ajar Inseminasi Buatan. Cetakan 1. Airlangga University Press. Surabaya.

Muino-Blanco, T. R. Perez-Pe, and J.A. Cebrian-Perez. 2008. Seminal plasma protein and sperm resistance to stress. J. Reprod. Domest. Anim. 4:18-31.

Mulyono, S dan B Sarwono. 2004. Beternak Domba Profilik. Penebar Swadaya. Jakarta.

Munfarida, Baiqotul. 2004. Hubungan Antara Libido dengan Produksi Semen Pejantan Sapi Bali dan Sapi Madura.[SKRIPSI]. Fakultas Peternakan Universitas Brawijaya. Malang.

Naz, R.K and K. Ahmed. 1994. Molecular Identities of Human Sperm Proteins That Bind Human Zona Pellucida : Nsture of Sperm -Zona Interection, Tyrosine Kinase Activity and Involment of FA-1. Mol. Reprod. Dev. 39, 397-408.

Rantam, F.A. 2003. Metode Imunology. Cetakan pertama Universitas Airlangga Press. Surabaya. Hal 79-98.

Sudarmono, A.S dan Y.B. Sugeng, 2003. Beternak Domba edisi revisi. Penebar Swadaya. Jakarta.

Toelihere, M.R. 1993. Inseminasi Buatan pada Ternak. Penerbit Angkasa. Bandung.

Watson PF. 2000. The causes of reduce fertility with cryopreserved semen. Anim Reprod Sci. 60-61:481-492. 